\title{
A Comparative Clinical Study of Gokshuradi Guggulu with Anupanabheda in The Management of Vatarakta with special reference to Gout
}

\author{
Research article
}

\section{Rimpaljeet Kaur1*, Amitabh Singh²}

1. Assistant Professor, Department of Roga Nidan and Vikriti Vigyan, Dayanand Ayurvedic College, Jalandhar. 2. H.O.D. and Professor, Department of Kayachikitsa, Desh Bhagat Ayurvedic College \& Hospital,

Mandigobindgarh, India.

\begin{abstract}
Gout is condition in which person become immobile and inactive due to joint pains and swelling. Gout occurs, when urate crystal deposition of in the joints. Vatarakta is considered as a vata pradhana vyadhi and rakta dushti. Gokshuradi Guggulu is having vatahara and raktashodhak properties. Guduchi kwatha selected as anupana because of its Rasayana, Vatashamaka, Balya, vedana sthapana and Ama pachana properties will help to disrupt the Samprapti vighatana of vatarakta. The objectives of the study were to evaluate the effect of Gokshuradi Guggulu with Anupanabheda in the management of Vatarakta and to compare the result of both groups. This study was randomized, parallel comparative clinical trial of two groups each of 20 patients. From OPD of DBACH Mandigobindgarh; 40 patients of vatarakta taken which were randomly divided into two groups. Group A, 20 patients for 60 days received Gokshuradi Guggulu $1 \mathrm{gm}$. BD with lukewarm water and Group B,20 patients received Gokshuradi Guggulu 1gm BD with Guduchi Kwatha for 60 days. In Group A, among 20 patient's 55\% patients showed moderate response and 45\% patients showed mild response. In Group B among 20 patients, $95 \%$ patients showed moderate response and $5 \%$ patients showed mild response. Both shows statistically highly significant results in both subjective and objective except erythema \& discoloration. Treatment modality in Group B (i.e. Gokshuradi Guggulu with Guduchi Kwatha) is effective in comparison of treatment modality in Group A (i.e. Gokshuradi Guggulu with lukewarm water).
\end{abstract}

Key Words: Vatarakta, Gout, Vatahara, Rakta dushti, Gokshuradi guggulu, Guduchi kwatha, Rasayana.

\section{Introduction}

In Ayurvedic texts, illnesses produced by the conjugation of vitiated Vata and Rakta cause several health ailments. Vatarakta is one of them; Vata prakopa, rakta dushti and obstruction in the path of vata is the core pathology in the disease. The pathology of this disease originates in blood, spreads through blood vessels and nerves and then finally get settled in the joints. In Vatarakta, the symptom which disturbs daytoday life of the patients i.e. severe joint pain, which primarily seen in Hasta-Pada-Mulagata sandhi (1) and then migrates to other joints in a way similar to Akhuvisha (2).

Vatarakta as mentioned in Ayurvedic texts have very close resemblance with Gout available in modern texts. Gout is musculoskeletal disorder, having the incidence of 2-26 per 1000 (3). In developing countries rate of gout has increased in recent decades. Gout is rare

\section{* Corresponding Author:}

\section{Rimpaljeet Kaur}

Assistant Professor,

Department of Roga Nidan and Vikriti Vigyan,

Dayanand Ayurvedic College,

Jalandhar, India.

Email Id: dr.rimpal@gmail.com in children and pre-menopausal females in India. Its effects men in their $40 \mathrm{~s}$ and $50 \mathrm{~s}$ and is common in female after menopause (4).

The predisposing factors are protein rich diet, consumption of alcohol and sedentary lifestyle. The disorder has been considered for the study keeping in mind the dire need of the hour to find some safe, sure and permanent cure effective for the disease.

Allopathic treatment has adverse effects like hepatic and renal impairment, which are contraindicated in pregnancy and lactation and harms the individual immune system. if Continuously NSAIDS are taken for long time which lead to gastric irritation, peptic ulcers etc (5).

On the other hand, Ayurveda with safe \& effective goodness has been pouring its valuable treasures to mankind since time unknown. In recent days, people are approaching back to nature and prefer to avoid synthetic preparations. Guggulu preparations are supposed to be one among the finest shamana aushadha in the vatavyadhis (6).

\section{Aims and objectives}

- To evaluate the effect of Gokshuradi Guggulu with two different Anupanas (i.e. Gokshuradi Guggulu with lukewarm water and Gokshuradi Guggulu with Guduchi Kwatha) in the management of Vatarakta.

- To Compare the result of both Groups 
Ethical committee clearance and CTRI registration

As this was a clinical study; Institutional Ethics Committee approval was taken prior to initiation of research vide letter no.-DBU/PGSAR/2403B/2014-15 dated 24/03/2014. This Clinical trial was registered under CTRI (Clinical Trials Registry - India) with no. CTRI/2017/03/008106.

Materials and Methods:

Preparation of the trial drug:

a. Gokshuradi guggulu (7): Ingredients of Gokshuradi Guggulu are shown in table 1.

\section{Table 1: Ingredients of Gokshuradi guggulu}

\begin{tabular}{|c|c|c|c|c|}
\hline $\begin{array}{l}\text { Sr. } \\
\text { No }\end{array}$ & $\begin{array}{c}\text { Name of } \\
\text { drug }\end{array}$ & $\begin{array}{c}\text { Botanical } \\
\text { name }\end{array}$ & $\begin{array}{l}\text { Part } \\
\text { used }\end{array}$ & $\begin{array}{c}\text { Quant } \\
\text { ity in } \\
\text { each } \\
\text { tab }\end{array}$ \\
\hline 1 & Gokshura & $\begin{array}{l}\text { Tribulus } \\
\text { terrestris } \\
\text { Linn. }\end{array}$ & Fruit & $\begin{array}{l}28 \\
\text { parts }\end{array}$ \\
\hline 2 & $\begin{array}{l}\text { Suddha } \\
\text { Guggulu }\end{array}$ & $\begin{array}{l}\text { Commiphora } \\
\text { mukul }\end{array}$ & Exudate & 7 parts \\
\hline 3 & Shunthi & $\begin{array}{l}\text { Zingiber } \\
\text { officinale } \\
\text { Roxb. }\end{array}$ & Rhizome & 1 part \\
\hline 4 & Maricha & $\begin{array}{l}\text { Piper nigrum } \\
\text { Linn. }\end{array}$ & Fruit & 1 part \\
\hline 5 & Pippali & $\begin{array}{l}\text { Piper } \\
\text { longum L. }\end{array}$ & Fruit & 1 part \\
\hline 6 & Haritaki & $\begin{array}{l}\text { Terminalia } \\
\text { chebula Retz. }\end{array}$ & Pericarp & 1 part \\
\hline 7 & Bibhitaki & $\begin{array}{l}\text { Terminalia } \\
\text { belerica } \\
\text { Roxb. }\end{array}$ & Pericarp & 1 part \\
\hline 8 & Amalaki & $\begin{array}{l}\text { Emblica } \\
\text { officinalis } \\
\text { Gaertn. }\end{array}$ & Pericarp & 1 part \\
\hline 9 & Musta & $\begin{array}{l}\text { Cyperus } \\
\text { rotundus } \\
\text { Linn. }\end{array}$ & Rhizome & 1 part \\
\hline
\end{tabular}

1. Guggulu Shodhana - Asudha guggulu (2 kg) shodhana was done by making dola yantra in triphala kwatha (16 lit.). Cooked till whole of sudha guggulu got mixed in kwatha (8).

2. Preparation of decoction - Gokshura (4 kg) was taken, \& 16 times of water added than that of ingredient, heating of kwatha till it remain 1/4th. Add purified (sudha) guggulu to this kwatha and cooked till it is thickened.

3. Addition of Prakshep dravyas - Powder of following drugs were added -Pippali, Shunthi, Marich, Triphla, Musta were taken 200 gms each.

4. Preparation of Vati (tablet) - Tablet of $375 \mathrm{mg}$ were made.

a. Guduchi Kwatha -20 gms of guduchi (already cut into pieces) is mixed with $320 \mathrm{ml}$ of water. This mixture is boiled on low heat till $1 / 8$ is left. When palatable (warm) then to be taken with the drug (9).
Selection of patients

Total 40 Patients suffering from vatarakta, fulfilling the criteria of Vatarakta (Gout) from OPD \& IPD of Kayachikitsa Dept. of Desh bhagat ayurvedic college and hospital, Mandigobindgarh Punjab; were selected randomly with coin toss method and divided into following 2 groups.

- Group-A: Gokshuradi Guggulu with Lukewarm Water in the dose of $1 \mathrm{gm}$ twice a day was given to 20 patients of Vatarakta for 60 days.

- Group-B: Gokshuradi Guggulu with Guduchi Kwatha in the dose of $1 \mathrm{gm}$ twice a day was given to 20 patients of Vatarakta for 60 days.

Study design: Open Randomized Parallel Group Trial.

\section{Inclusion Criteria}

Patients of age group between 16-70 years; having clinical signs and symptoms of Vatarakta and having serum uric acid level $>7 \mathrm{mg} / \mathrm{dl}$ with associated features like joint pain and inflammation were included in the study.

\section{Exclusion Criteria}

- Any other joint inflammatory disorder like RA.

- Uncontrolled Diabetes and Hypertension. Chronic renal disease.

- Patients having chronicity more than 10 years.

- Disease associated with marked joint destruction.

- Hemarthrosis, Koch arthritis, Septic arthritis.

- Severe multi organ syndromes.

- Patients suffering from major systemic illness.

- Pregnant and lactating women.

- Any other state thought fit for exclusion.

\section{Laboratory Investigations required}

- Blood test - $\mathrm{Hb}$ gm\%, T.L.C., D.L.C., E.S.R., F.B.S.

- Bio-Chemistry - S. Uric acid, L.F.T., R.F.T.

- Urine Examination - Routine and Microscopic examination.

- Radiological Examination if required - X-Ray of joints.

\section{Follow-Up:}

All patients are influenced to come for the follow up study after every 15 days i.e. $15^{\text {th }}, 30^{\text {th }}$, 45 th $\& 60^{\text {th }}$ days. During every visit proper assessment were made based on sign and symptoms and laboratory Investigations (only S. Uric acid \& ESR).

\section{Assessment criteria}

Patients were diagnosed based on performa prepared with signs and symptoms of Vatarakta. The improvement was assessed on the relief found in the cardinal features of the disease. To assess the effect of therapy all the sign and symptoms were assigned score depending upon their severity as elaborated below: 


\section{Subjective Parameters}

Table 2: Showing subjective parameters for Vatarakta

\begin{tabular}{l|l|l|}
\hline 1 & Pain Index & Shoola \\
\hline 2 & Swelling Index & Shotha \\
\hline 3 & Erythema Index & Raga \\
\hline 4 & Discoloration Index & Tvak Vaivarnyata \\
\hline 5 & Burning sensation Index & Vidaha \\
\hline 6 & Stiffness Index & Stabdhata \\
\hline 7 & Tenderness Index & Sparsha asahyata \\
\hline 8 & Fatigue Index & Shithilta \\
\hline & Following objective scale with numerical \\
values & was used to assess the severity of above- \\
mentioned subjective criteria (table 3 to 10):
\end{tabular}

\begin{tabular}{|l|l|}
\multicolumn{1}{|c|}{} & $\begin{array}{c}\text { Table 3: Showing grading of } \\
\text { joint pain (Sandhi Shoola) }\end{array}$ \\
\hline Score & Joint Pain Status \\
\hline 0 & No Pain \\
\hline 1 & Mild Pain \\
\hline 2 & Pain on movement \& relieved on rest \\
\hline 3 & Constant Pain \\
\hline 4 & Severe Pain disturbing sleep \\
\hline
\end{tabular}

Table 4: Showing grading of Swelling of Joints (Sandhi Shotha)

\begin{tabular}{l|l|} 
Score & Status \\
\hline 0 & No Swelling \\
\hline 1 & Mild Swelling \\
\hline 2 & Moderate Swelling \\
3 & Severe Swelling without loss of movements \\
\hline 4 & Severe Swelling with loss of movements
\end{tabular}

\section{Table 5: Showing grading for} Redness of Joint (Raga)

\begin{tabular}{|l|l|} 
Score & Status \\
\hline 0 & No Redness \\
\hline 1 & Mild Redness \\
\hline 2 & Moderate Redness \\
3 & Severe Redness \\
\hline 4 & Joint Dusky Red \\
\hline
\end{tabular}

Table 6: Showing grading

\begin{tabular}{|l|l|}
\multicolumn{2}{c|}{ Discoloration of the skin (Tvak vaivarnyata) } \\
\hline Score & Status \\
\hline 0 & No Discoloration \\
\hline 1 & Mild Discoloration of The Skin \\
2 & Moderate Discoloration of The Skin \\
3 & Severe Discoloration of The Skin \\
\hline
\end{tabular}

Table 7: Showing grading of Burning Sensation (Vidaha)

\begin{tabular}{|l|l|}
\hline Score & Status \\
\hline 0 & No Burning Sensations \\
\hline 1 & Mild Burning Sensation \\
\hline 2 & Moderate Burning Sensation \\
\hline 3 & Severe Burning Sensation \\
\hline 4 & $\begin{array}{l}\text { Very Severe Burning Sensation Causing } \\
\text { Disturbance In Sleep }\end{array}$ \\
\hline
\end{tabular}

Table 8: Showing grading Stiffness (Stabdhata)

\begin{tabular}{|c|c|}
\hline Score & Status \\
\hline 0 & No stiffness \\
\hline 1 & Stiffness lasting for few minutes to 1 hour \\
\hline 2 & Stiffness lasting for 1 to 8 hours \\
\hline 3 & $\begin{array}{l}\text { Stiffness lasting for more than } 8 \text { hours but } \\
\text { not }\end{array}$ \\
\hline 4 & Throughout the day \\
\hline
\end{tabular}

Table 9: Showing grading of Tenderness (Sparsha Asahyata)

\begin{tabular}{|c|c|}
\hline Score & Tenderness status \\
\hline 0 & No Tenderness \\
\hline 1 & Patient says it is Tender \\
\hline 2 & Patient says it is Tender and winces \\
\hline 3 & $\begin{array}{l}\text { Patient says it is Tender, winces \& withdraws } \\
\text { the limb. }\end{array}$ \\
\hline 4 & $\begin{array}{l}\text { Patient does not allow to touch the affected } \\
\text { part }\end{array}$ \\
\hline
\end{tabular}

Table 10: Showing grading of Fatigue (Shithilta)

Score Status

$0 \quad$ No fatigue

1 Fatigue on doing heavy work

2 Fatigue on doing accustomed work

3 Fatigue on doing less than accustomed work

$4 \quad$ Fatigue even at rest

\section{Objective parameters}

Serum Uric acid level and ESR (table $11 \& 12$ ).

Table 11: Showing grading of Serum Uric Acid

\begin{tabular}{|l|l|l|} 
Serum Uric Acid & Lab Value (mg/dl) & Grade \\
\hline Normal & $0-6$ & 0 \\
Mild & $6.1-7$ & 1 \\
\hline Moderate & $7.1-8$ & 2 \\
\hline Severe & 8 \& Above & 3
\end{tabular}

Table 12: Showing grading of ESR

\begin{tabular}{l|l|l|} 
ESR & Lab Value $(\mathbf{m m} / \mathbf{h})$ & Grade \\
\hline Normal & Upto 7 & 0 \\
\hline Mild & $7-10$ & 1 \\
\hline Moderate & $10-15$ & 2 \\
\hline Severe & Above 15 & 3 \\
\hline
\end{tabular}

\section{Criteria for overall assessment}

Overall results were established in terms of percentage relief obtained in criteria of assessment.

\begin{tabular}{|l|l|}
\hline Complete Remission & $\begin{array}{l}100 \% \text { relief in signs \& } \\
\text { symptoms }\end{array}$ \\
\hline Marked improvement & $75-99 \%$ improvement \\
\hline Moderate improvement & 50 to $74 \%$ improvement \\
\hline Mild improvement & $\begin{array}{l}25-49 \% \text { improvement } \\
\text { No improvement }\end{array}$ \\
\hline Worsened problem & $\begin{array}{l}\text { Aggravation of signs and } \\
\text { symptoms }\end{array}$ \\
\hline
\end{tabular}




\section{Results and discussion}

The effect of trial drug in 40 patients for duration of 60 days, various assessment criteria were obtained after statistical analysis of the data and is presented in tabular form as below

Table 13: Effect of Therapy on Clinical Features of Gout in Group A

\begin{tabular}{|c|c|c|c|c|c|c|c|c|c|c|}
\hline \multirow[t]{2}{*}{ S.No } & \multirow[t]{2}{*}{ Symptoms } & \multirow[t]{2}{*}{$\mathbf{N}$} & \multicolumn{2}{|c|}{ Mean Score } & \multirow[t]{2}{*}{$\%$ Relief } & \multirow[t]{2}{*}{ SD } & \multirow[t]{2}{*}{ T Value } & \multirow[t]{2}{*}{ SE } & \multirow[t]{2}{*}{ P Value } & \multirow[t]{2}{*}{ Sig. } \\
\hline & & & BT & AT & & & & & & \\
\hline 1 & Localized Joint Pain & 18 & 2.85 & 1.15 & 59.64 & 0.865 & 8.794 & 0.193 & $<0.001$ & HS \\
\hline 2 & Swelling of Joint & 15 & 2.15 & 0.95 & 55.81 & 0.834 & 6.439 & 0.186 & $<0.001$ & HS \\
\hline 3 & Erythema & 11 & 1.10 & 0.40 & 63.64 & 0.733 & 4.273 & 0.164 & $<0.001$ & HS \\
\hline 4 & Discoloration & 7 & 0.45 & 0.05 & 88.88 & 0.598 & 2.990 & 0.134 & 0.008 & $\mathrm{~S}$ \\
\hline 5 & Burning Sensation & 12 & 1.35 & 0.60 & 55.56 & 0.716 & 4.682 & 0.160 & $<0.001$ & HS \\
\hline 6 & Stiffness & 16 & 1.90 & 0.80 & 57.89 & 0.788 & 6.242 & 0.176 & $<0.001$ & HS \\
\hline 7 & Tenderness & 14 & 1.70 & 0.60 & 64.70 & 0.852 & 5.772 & 0.191 & $<0.001$ & HS \\
\hline 8 & Fatigue & 15 & 2.10 & 0.80 & 61.90 & 0.865 & 6.725 & 0.193 & $<0.001$ & HS \\
\hline
\end{tabular}

Table 14: Effect of Therapy on Lab Parmeters of Gout in Group A

\begin{tabular}{|c|l|c|c|c|c|c|c|c|c|}
\hline S. & \multicolumn{1}{|c|}{ Symptom } & N & Mean Score & \% Relief & SD & SE & P value & Significance \\
No. & \multicolumn{1}{|c|}{ BT } & AT & . & & & & \\
1 & S. Uric Acid & 20 & 2.75 & 2.05 & 25.45 & 0.470 & 0.105 & $<0.001$ & HS \\
\hline 2 & ESR & 20 & 2.5 & 1.95 & 22 & 0.510 & 0.114 & $<0.001$ & HS \\
\hline
\end{tabular}

Table 15: effect of Therapy on Clinical features of gout in Group B

\begin{tabular}{c|l|c|c|c|c|c|c|c|c|c|}
$\begin{array}{c}\text { S. } \\
\text { No. }\end{array}$ & \multicolumn{1}{|c|}{ Symptom } & N & \multicolumn{2}{c|}{ Mean Score } & \% Relief & SD \pm & SE \pm & T value & p value & Sig \\
\hline 1 & Localized joint pain & 15 & 2.40 & 0.650 & 72.92 & 1.118 & 0.250 & 7.000 & $<0.001$ & HS \\
\hline 2 & Swelling of joint & 17 & 2.650 & 0.850 & 67.92 & 0.587 & 0.200 & 9.000 & $<0.001$ & HS \\
\hline 3 & Erythema & 12 & 1.15 & 0.50 & 56.52 & 0.587 & 0.131 & 4.951 & $<0.001$ & S \\
\hline 4 & Discoloration & 5 & 0.350 & 0.200 & 42.85 & 0.366 & 0.082 & 1.831 & 0.083 & NS \\
\hline 5 & Burning sensation & 10 & 1.300 & 0.450 & 65.38 & 0.933 & 0.209 & 4.073 & $<0.001$ & HS \\
\hline 6 & Stiffness & 17 & 2.150 & 0.850 & 60.465 & 0.865 & 0.193 & 6.725 & $<0.001$ & HS \\
\hline 7 & Tenderness & 12 & 1.50 & 0.50 & 66.66 & 0.918 & 0.205 & 4.873 & $<0.001$ & HS \\
\hline 8 & Fatigue & 11 & 1.70 & 0.65 & 61.76 & 1.146 & 0.256 & 4.098 & $<0.001$ & HS \\
\hline
\end{tabular}

Table 16: Effect of Therapy on Lab parameters of Gout in Group B

\begin{tabular}{|c|c|c|c|c|c|c|c|c|c|}
\hline \multirow[t]{2}{*}{ S. No. } & \multirow[t]{2}{*}{ Parameter } & \multirow[t]{2}{*}{$\mathbf{n}$} & \multicolumn{2}{|c|}{ Mean Score } & \multirow{2}{*}{$\begin{array}{c}\% \\
\text { Relief }\end{array}$} & \multirow[t]{2}{*}{ SD \pm} & \multirow[t]{2}{*}{$\mathbf{S E} \pm$} & \multirow[t]{2}{*}{ P value } & \multirow[t]{2}{*}{ Significance } \\
\hline & & & BT & AT & & & & & \\
\hline 1 & S. Uric Acid & 20 & 2.55 & 0.85 & 66.66 & 0.470 & 0.105 & $<0.001$ & HS \\
\hline 2 & ESR & 20 & 2.75 & 1.55 & 43.63 & 0.696 & 0.156 & $<0.001$ & HS \\
\hline
\end{tabular}

Table 17: Comparative effect on clinical features in Group A and B

\begin{tabular}{|c|c|c|c|c|c|c|c|c|}
\hline \multirow{2}{*}{$\begin{array}{l}\text { S. } \\
\text { No }\end{array}$} & \multirow[t]{2}{*}{ Symptom } & \multicolumn{2}{|c|}{$\%$ Relief } & \multirow[t]{2}{*}{$\mathbf{S D} \pm$} & \multirow[t]{2}{*}{$\mathbf{S E} \pm$} & \multirow[t]{2}{*}{ T value } & \multirow[t]{2}{*}{ p value } & \multirow{2}{*}{$\begin{array}{l}\text { Significan } \\
\text { ce }\end{array}$} \\
\hline & & $\mathbf{A}$ & B & & & & & \\
\hline 1 & Localized joint pain & 59.64 & 72.92 & 1.118 & 0.250 & -0.158 & 0.875 & NS \\
\hline 2 & Swelling of joint & 55.81 & 67.92 & 0.894 & 0.200 & -0.600 & 0.03 & $\mathrm{~S}$ \\
\hline 3 & Erythema & 63.64 & 56.52 & 0.587 & 0.131 & 0.238 & 0.813 & NS \\
\hline 4 & Discoloration & 88.88 & 42.85 & 0.366 & 0.082 & 1.594 & 0.119 & NS \\
\hline 5 & Burning sensation & 55.56 & 65.38 & 0.933 & 0.209 & -0.380 & 0.706 & NS \\
\hline 6 & Stiffness & 57.89 & 60.46 & 0.865 & 0.193 & -0.765 & 0.449 & NS \\
\hline 7 & Tenderness & 64.70 & 66.66 & 0.918 & 0.205 & 0.357 & 0.723 & NS \\
\hline 8 & Fatigue & 61.90 & 61.76 & 1.146 & 0.256 & 0.779 & 0.441 & NS \\
\hline
\end{tabular}

Table 17: Comparative effect on Lab parameters in Group A and B

\begin{tabular}{|r|c|r|r|r|r|r|r|} 
Sr. No. & Parameter & \multicolumn{1}{l}{ \% Relief } & \multicolumn{1}{l}{ SD } & SE & p value & Significance \\
\hline 1 & & A & B & & & & \\
\hline 2 & S. Uric acid & 25.454 & 66.666 & 0.470 & 0.105 & $<0.001$ & HS \\
\hline
\end{tabular}


Fig. 1: Comparative effect on clinical features in Group A and B

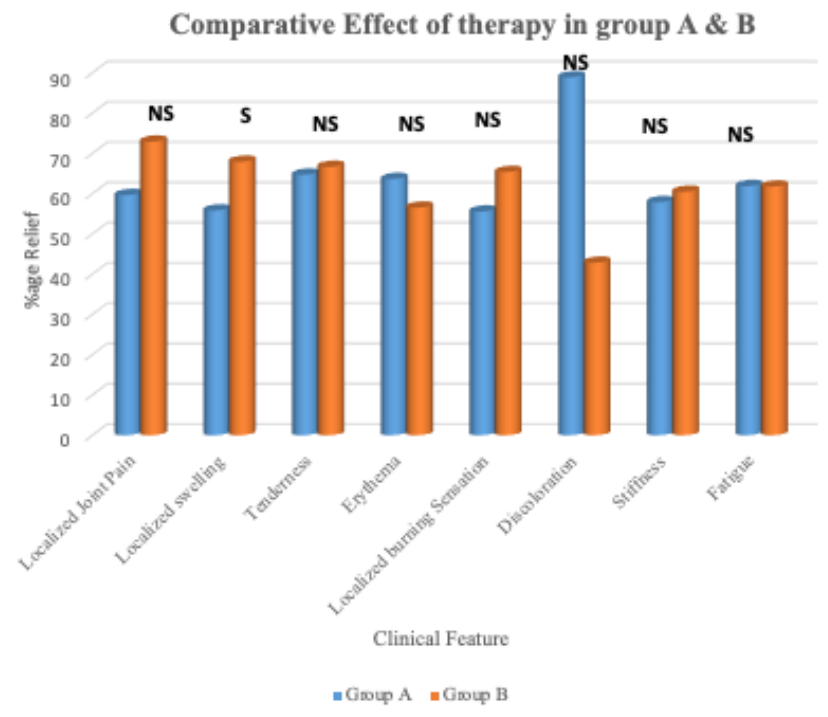

Fig 2: Comparative effect on clinical features in Group A and B

\section{Comparison of Overall Effect of Both Groups}

It is observed from the comparative study that no patient got complete remission or marked improvement in both the groups whereas number of patients improved moderately was 11 and 19 in group A \& B respectively. 09 patient in group A and 01 patients in group B got mild improvement in sign \& symptoms. No patient had zero improvement or worsening of disease in any group (Table no. 19).

Table 19: Comparison of overall effect of both the groups

\begin{tabular}{|l|c|c|}
\multicolumn{1}{c|}{ Overall assessment } & No. of patients in group A & No. of patients in group B \\
\hline Complete remission & 0 & 0 \\
\hline Marked improvement & 0 & 0 \\
\hline Moderate improvement & 11 & 19 \\
\hline Mild improvement & 9 & 1 \\
\hline No improvement & 0 & 0 \\
\hline Deteriorated & 0 & 0
\end{tabular}

\section{Probable mode of action}

Action of drug is based on 5 mechanism of actions or attributes; namely rasa, guna, virya and vipaka along with certain specific properties called prabhava. The drugs jointly act as an antagonist to the morbid dosha and dushya and cause 'Samprapti Vighatana'.

In the trial drug guggulu is associated with 8 other drugs- Gokshura, Musta, Haritaki, Amalaki, Bibhitaki, Pippali, Marich and Shunthi as the main ingredients. The probable effect of all the constituent drugs of gokshuradi guggulu can be explained as further.

Table 20: Showing Rasa, Guna, Virya, Vipaka and Prabhava of drugs

\begin{tabular}{|c|c|c|c|c|c|c|}
\hline S.N. & Drug & Rasa & Guna & Vipaka & Virya & Doshghanata \\
\hline 1 & Gokshura & Madhura & Guru, Snigdha & Madura & Sheeta & Vatapittashamaka \\
\hline 2 & $\begin{array}{l}\text { Shudha } \\
\text { Guggulu }\end{array}$ & Katu, Tikita, Kashya & $\begin{array}{l}\text { Laghu, Ruksha, } \\
\text { Sara,Vishad, } \\
\text { Sukshma, Tikshna, } \\
\text { Sara, }\end{array}$ & Katu & Ushna & Vatashamaka \\
\hline 3 & Musta & Katu, Tikita, Kashya & Laghu, Ruksha & Katu & Sheeta & Pitta Kaphahara \\
\hline 4 & Amalaki & $\begin{array}{l}\text { Madhura, Amla, } \\
\text { Katu, Tikita, Kashya }\end{array}$ & Laghu, Ruksha & Madhura & Sheeta & $\begin{array}{l}\text { Tridoshashamaka } \\
\text { (Pitta shamaka) }\end{array}$ \\
\hline 5 & Bibhitaki & Kashya & Laghu, Ruksha & Madhura & Ushna & $\begin{array}{l}\text { Tridoshashamaka } \\
\text { (Kaphapittashamk) }\end{array}$ \\
\hline 6 & Haritaki & $\begin{array}{l}\text { Madhura, Amla, } \\
\text { Katu, Tikita, Kashya }\end{array}$ & Laghu, Ruksha & Madhura & Ushna & $\begin{array}{l}\text { Tridoshashamaka } \\
\text { (Vatashamaka) }\end{array}$ \\
\hline 7 & Pippali & Katu, Tikita,Madhura & Laghu, Snigdha & Madhura & $\begin{array}{l}\text { Anushan- } \\
\text { sheeta }\end{array}$ & Kaphavatashamak \\
\hline
\end{tabular}




\begin{tabular}{|l|l|l|l|l|l|l|}
\hline $\mathbf{8}$ & Shunthi & Katu & Laghu, Snigdha & Madhura & Ushna & Vatakaphashamaka \\
\hline $\mathbf{9}$ & Marich & Katu, Tikita & Laghu, Ruksha, & Katu & Ushna & Vatakaphashamaka \\
\hline $\mathbf{1 0}$ & Guduchi & Tikita, Kashaya & Laghu & Madhura & Ushna & Tridoshaghana \\
\hline
\end{tabular}

Rasa

Due to predominance of tikta, kashaya rasa, it pacifies pitta dosha. Tikta rasa is said to have deepana karma by which it corrects mandagni and pachana karma which helps in amapachana. Both kashaya as well as tikta rasa also reduces the kled guna of rakta, kapha and ama. It has also lekhana and shoshana guna which clears the srotas and sira marga, avrita with sama rakta.

\section{Guna}

Laghu guna of most of the constituent drugs like trikatu has srotoshodhaka, agnideepak properties. Other than this, being ruksha guna pradhan, it helps in absorption of mala and ama.

\section{Virya}

As most of the drugs in trial drug have ushna virya, it has vatakaphahara property and said to be deepana and pachana. It also helps in vilayan of doshas which is necessary step in bringing shakhagata dosha towards koshtha.

\section{Vipaka}

Madhura vipaka is predominant in the drug which has snigdha and vatapittashamaka properties and helps in easy passage of urine and stool.

\section{On the basis of dosha Karma}

In general, the formulation has tridosha shamak as well as raktashodhaka properties. Most of the drugs selected have their rasayana guna. Rasayana is said to be 'vyadhi vidhwansi' (which means effective in curing the disease). It helps in maintaining homeostasis between all doshas and dhatus by its action through rasa, guna, virya and vipaka.

\section{Pharmacological actions of drugs Deepana karma}

Most of the drugs i.e. guduchi, amalaki, haritaki, mustak, pippali, marich, and shunthi exhibit deepana guna due to pradhanata of vayu and agni mahabhoota. As agnimandya is one of the factors in causation of disease, it corrects abnormality in jatharagni as well as dhatvagni.

\section{Pachana karma}

The formulation contains drugs having pachana guna like guduchi, haritaki, mustak and trikatu. Pachana dravyas are agni and vayu pradhan, enhance jaran shakti and helps in ama pachana. As sama rakta cause sthan sanshraya in asthivaha srotas by obstructing the normal pathway of vata, pachana dravyas help in clearing that obstruction caused by ama.

\section{Vedanasthapana}

Guggulu, guduchi, haritaki, vibhitak, gokshur pippali, marich and shunthi, all these drugs are said to have vedanasthapak (analgesic) action. One function of vata is 'Pravartak cheshtanam uchchavachanam'. So, when there is vata prakopa, this perception of senses aggravates and manifests in the form of vedana. Most of these drugs are ushna virya due to which they pacify vata dosha and vedana as well.

\section{Vishyandan and srotoshodhan}

Means liquification of deeply embedded dosha for their easy flow.

According to acharya Chakrapani, vishyandan and vilayan both are synonyms. A drug should have ushna, tikshna guna for vilayan karma. Among all 9 drugs present in formulation, 6 drugs are known to be ushna virya and 3 drugs (Guggul, Marich, Shunthi) are tikshna in nature, due to which they help in dissolving doshas as well as ama. Tikshna dravya has also the property of lekhan karma which leads to srotoshodhan at the level of microchannels.

\section{Shothahara and doshapkarshana}

The drugs, by above mentioned karma help in moving doshas from shakha to koshtha. These doshas when expelled into koshtha, are excreted out of body by different means of urine, stool etc.

Besides all these, some of these drugs have Shothahara, vatanuloman, rasayana and balya properties which help in relieving the symptoms of vatarakta.

\section{Pharmaco-dynamical aspects of Gokshuradi Guggulu in Modern parlance}

The management of hyperuricemia goes through two ways:

1. Management of Symptoms

2. Breaking down the Pathology- this comprises of two set of medications:

a. Inhibition of Xanthine Oxidase- Xanthine Oxidase inhibitors decrease the production of Uric Acid by interfering with Xanthine Oxidase enzyme.

b. Excretion of Uric acid through UricosuricUricosuric increase the excretion of uric acid by reducing its re-absorption once the kidneys have filtered it out of the blood.

An important content of Gokshuradi Guggulu is Guggulu which possesses the properties of antiinflammatory $(10,11)$, antioxidant $(12,13)$, Uricosuric (14), anti-rheumatoidal (15) helps in breaking the pathophysiology of Gout.

Gokshur showed better anti-inflammatory results and analgesic action. According to a clinical study, significant analgesic effect of methanolic extract of gokshur was observed (16).

Triphala works as a Xanthine Oxidase inhibitor (17) like Allopurinol which suppresses the production of Uric Acid. Its content Haritaki has antioxidant $(18,19)$ and adaptogenic $(20)$ properties which help in 
the recovery and healing of deformed tissue. Bibhitaki, another content of Triphala has nephro-protective (21) function which retards the Urolithiasis and dissolves already formed stones in kidney while Amalaki has antiinflammatory, analgesic, antipyretic (22) and antioxidant (23) properties which help reducing the local and systemic inflammatory effects of Gout.

Maricha has Antioxidant (24), immunemodulatory (25) property subsides the hyperactive immune responses precipitated due to Uric Acid. Vasodilatory property (26) increases the blood circulation to the affected joint and enhances the process of phagocytosis of antigen-antibody complexes responsible for hypersensitivity which gave rise to inflammation.

Piperine found in pippali and marich significantly inhibited the production of two important pro inflammatory mediators, $\mathrm{IL}_{6}$ and $\mathrm{PGE}_{2}$. The inhibition of $\mathrm{PGE}_{2}$ production is important due to its central role in triggering pain. It has been seen that P. longum root has weak opioid but potent NSAID type of analgesic activity. As per Ayurveda vedana is chiefly manifestation of vata dosh prakopa. Vata due to its sheeta guna exhibits vedana. Most of the drugs in gokshuradi guggulu are ushna virya which inhibit the sheeta guna of vata thus giving relief of pain.

Shunthi is an inhibitor of both prostaglandin and leukcotrine biosynthesis $(27,28)$ and its beneficial effects could be, to a large extent, due to these inhibitory effects. It is a potent anti-inflammatory agent and the active principles include sesquiterpene lactones (29).

Musta rhizomes are considered as astringent, diaphoretic, diuretic, analgesic, antispasmodic (30), antiarthritis, antiinflammatory, antipyretic, analgesic, antidiabetic, antidiarrheal, cytoprotective, antimutagenic, antimicrobial, antioxidant and apoptotic (31).

In this way, Gokshuradi Guggulu has all the aspects of Pharmaco-therapeutic effect required for the management of Hyperuricemia induced Gout like Antiinflammatory, Antioxidant, Immuno-modulator, Xanthine Oxidase Inhibitor, Uricosuric and Diuretic effects.

The effect of Guduchi kwatha is due to antiinflammatory $(32,33)$ activity of Amrita which reduces the inflammation and gives symptomatic relief as well as its uricosuric action which excretes excess amounts of Uric Acid from the body (34).

Thus, Gokshuradi Guggulu with Guduchi kwatha which helped in reducing the symptoms and excreting the surplus amount of Uric Acid from the body. Hence, Gokshuradi Guggulu with guduchi kwatha anupana has shown comparatively better results over Gokshuradi Guggulu with lukewarm water anupana.

\section{Conclusion}

Treatment modality Gokshuradi Guggulu with Guduchi Kwatha shows better efficacy in reliving subjective features as well as objective features than
Gokshuradi Guggulu with lukewarm water. The trial drug gokshuradi guggulu used for study in both groups is a good combination of vedanasthapan, shothaghna, deepana and amapachak dravyas. guduchi, triphala, guggulu and trikatu with their tridosha shamak mainly vatanashak, rasayana, balya raktprasadaka property helps in maintaining homeostasis in dhatus as well as doshas.

\section{References}

1. Tripathi B, Charaka Samhita-Chikitsa Sthana-29/12, Chaukhambha Prakashan Varanasi.;2011. 983p.

2. Shastri A.D, Sushruta Samhita with Ayurveda Tattva Sandipika- Hindi Commentary Nidan sthana-1/48, Chaukhambha Sanskrit Sansthana Varanasi; Reprint 2007. 232p.

3. Siddharth N. Shah et.al, A.P.I. Textbook of medicine. $8^{\text {th }}$ ed.Ch.7. Vol.1. 2008 Mumbai: The Association of physicians of India; 2008. 284p.

4. Kumar P. Clark M, Kumar \& Clark's Clinical Medicine; $7^{\text {th }}$ ed. Ch.10. Vol.2. Spain: Saunders Elsevier Limited; 2009. 536p.

5. Fauci A.S. et.al, Harrison's Principles of Internal Medicine. 17th ed. Ch.327. Vol. 2. New York: Mc Graw -Hill Medical Publishing Division; 2008. $2165 \mathrm{p}$.

6. Tripathi B, Charaka Samhita-Chikitsa Sthana-28, Chaukhambha Prakashan Varanasi.;2011. 970p.

7. Tripathi B, Sharangdhara Samhita of Pandit Sharangdhara Acharya with Dipika - Hindi Commentary-Madhyama Khanda-7/84, Chaukhambha Surbharati Prakashan Varanasi; Reprint 2011.206p.

8. Pandeya G., Raschandashu Rasratana SamgrahaPurvakhanda, Chaukhambha Krishandas Academy Varanasi; 2010. 65p.

9. Shastri R., Chakradatta of Shri Charkarpni Datta with the Padarthabodhini Hindi CommentaryVataraktaadhikara 23/9, Chaukhambha Surbharati Prakashan Varanasi; 2012. 111p.

10. Shishodia S, Aggarwal BB. Guggulu sterone inhibits NF -kappa B and I kappa B alphakinase activation, suppresses expression of anti-apoptopic gene products and enhance apoptosis. J Biol. Chem. 2004; 279(45): 47148-47158.

11. Thapa DM, Dongra J. Nodulocystic acne: oral Guggulu lipid versus tetracycline. J Dermatol 1994; 21: 729 .

12. Chander R, Khanna AK, Pratap R. Antioxidant activity of Guggulu sterone, the active principle of guggulu lipid from Commiphora mukul. Journal of Medicinal Aromatic Plant Sciences 2002; 24: 370.

13. Singh RB, Niaz MA, Ghosh S. Hyperlipidemic and antioxidant effect of Commiphora mukul as an adjunct to dietary therapy in patients with hypercholesteremia. Cardiovascular Drug Therapy 1994; 8(4): 659.

14. Bombardelli E, Spelta M. Commiphora mukul extracts and therapeutic applications thereof. US patent application no. 5273747, 1993. 
15. Jachak SM, Saklani A. Challenges and opportunities in drug discovery from plants. Curr. Sci. 2007; 92: 1251-1257.

16. Heidari MR, Mehrabani M, Pardakhty A,et.al. The Analgesic Effect of Tribulus terrestris Extract and Comparison of Gastric Ulcerogencity of the Extract with Indomethacine in Animal Experiments. Annals of the New York Academy of Sciences 2007; $1095(2007)$ : 418-427.PubMed PMID: 17404054.doi:10.1196/annals.1397.045.

17. Naik G H, et. al. Free radical scavenging reactions and phytochemical analysis of Triphala, an Ayurvedic formulation, Current Science, April 2005; 90(8).

18. Lee HS, Won NH, Kim KH. Antioxidant effects of aqueous extract of Terminalia chebula in vivo and in vitro. Biol. Pharm. Bull 2005; 28(9): 1639-1644.

19. Lee H S, Jung S H, Yun BS. Isolation of chebulic acid from Terminalia chebula Retz. and its antioxidant effect in isolated rat hepatocytes. Arch. Toxicoly 2007; 81(3): 211-218.

20. Rege N N, Thatte U M, Dahanukar S A. Adaptogenic properties of six Rasayana Herbs used in Ayurvedic medicines. Phytotherapy Res. 1999; 13: 275-291.

21. Jadona A, Bhadauriaa M, Shukla S. Protective effect of Terminalia belerica Roxb. and gallic acid against carbon tetrachloride induced damage in albino rats. Journal of Ethnopharmacology 2007; 109(2): 214-218.

22. Sharma S K. Perianayagam B J, Joseph A, Christina A J M. Anti-inflammatory activity of ethanol an aqueous extract of Emblica officinalis Geartn fruits. Hamdard Medicus 2003; 46: 75-78.

23. Bhattacharya A, Chatterjee A, Ghosal S, Bhattacharya SK. Antioxidant activity of active tannoid principles of Emblica officinalis (amla), Indian J. Exp. Biol; 1999; 37: 676-680.

24. Manosroi A, Masahiko A B E, Manosroi J. Comparison of antioxidant activity of extracts from the seeds of white pepper (Piper nigrum Linn.) to commercial antioxidants in $2 \%$ hydroquinone cream. J Cosmet Sci. 1999; 50: 221-229.
25. Sunila ES, Kuttan G. Immunomodulatory and antitumor activities of Piper longum Linn. and piperine. J Ethanopharmacol 2004; 90(2-3): 339-346.

26. Shoji N, Umeyama A, Saito N, Takemoto T, Kajiwar O. Dehydropipernonaline, an amide possessing coronary vasodilating activity isolated from Piper longum Linn. J Pharm Sci 1986; 75(12): 1188-1189.

27. Srivastava, K.C. and Mustafa, T. (1992). Ginger (Zingiber officinale) in rheumatism and musculoskeletal disorders. Med. Hypotheses, 39: 342.

28. Srivastava, R. and Srimal, R.C. (1985). Modificat ion of certain inflammation induced biochemical changes by curcumin. Ind. J. Med. Res., 81: 215-223.

29. Kohli, K.; Ali, J.; Ansari, M.J. and Raheman, Z. (2005). Curcumin: a natural anti-inflammatory agent. Indian J. Pharmacol., 37: 141-147.

30. Sivapalan, S.R. (2013). Medicinal uses and pharmacological activities of Cyperus rotundus Linn - a review. Int. J. Sci. Res. Publications, 3: 1-8.

31. Singh, N.; Pandey, B.R.; Verma, P.; Bhalla, M. and Gilca, M. (2012). Phyto-pharmocotherapeutics of Cyperus rotundus Linn (Motha): An overview. Indian J. Nat. Prod. Resources, 3: 467-476.

32. Jana U, Chattopadhyay RN, Shw BP. Preliminary studies on anti-inflammatory activity of Zingiber officinale Rosc., Vitex negundo Linn. and Tinospora cordifolia (Willid) Miers in albino rats. Indian J Pharm 1999; 31: 232-233.

33. Sharma AK, Singh RH. Screening of antiinflammatory activity of certain indigenous drugs on carrageen in induced hind paw oedema in rats. Bull Medico Ethenobot Res. 1980; 1(2): 12.

34. Nayampalli SS, Ainapure SS, Samant BD, Kudtarkar RG, Desai NK, Gupta KC et al. A comparative study of diuretic effects of Tinospora Cordifolia and Hydrochloro-thiazide in rats and a preliminary phase I study in human volunteers. J Post grad Med 1988; 34: 233-236. 